\title{
Development of mouse embryos cryopreserved by vitrification
}

\author{
W. F. Rall*, M. J. Wood, C. Kirby and D. G. Whittingham \\ MRC Experimental Embryology and Teratology Unit, Woodmansterne Road, Carshalton, \\ Surrey SM5 4EF, U.K.
}

\begin{abstract}
Summary. Eight-cell mouse embryos were cryopreserved by vitrification in a concentrated solution of dimethylsulphoxide, acetamide, propylene glycol and polyethylene glycol. This solution (designated VS1) does not crystallize when cooled to subzero temperatures but instead forms a glassy transparent solid. Embryos were exposed in three steps to a stock VS1 solution or a saline solution containing $90 \%$ of the cryoprotectants in the stock VS1 (90\% VS1) and then the suspensions were vitrified by rapid cooling in liquid nitrogen. Of 568 embryos vitrified in $90 \% \mathrm{VS} 1,80 \%$ developed in vitro and 98 normal fetuses or young ( $17 \%$ of the total) were produced after transfer to pseudopregnant recipients. By contrast, $22 \%$ of 153 embryos vitrified in the stock VS1 developed in vitro, but only one normal fetus was obtained after transfer.

These results demonstrate that normal fetuses and young can be produced from embryos cryopreserved by the simple and rapid method of vitrification.
\end{abstract}

\section{Introduction}

Conventional cryopreservation procedures for mammalian embryos require careful control of the quantity of ice formed during cooling and warming (Leibo, 1977; Rall et al., 1984b). Initial experiments on the cryopreservation of mouse embryos by freezing indicate that three factors are important for survival: the presence of molar concentrations of a cryoprotective solute, the induction of ice crystal growth by seeding the supercooled suspension, and the use of slow cooling $\left(<1^{\circ} \mathrm{C} / \mathrm{min}\right.$ ) to at least $-60^{\circ} \mathrm{C}$ and slow warming (Whittingham et al., 1972; Wilmut, 1972; Leibo et al., 1974; Whittingham, 1977). Modification of the procedure permitted the cryopreservation of other mammalian embryos, and has led to simplified procedures for cooling, warming and dilution of the cryoprotectants (Willadsen, 1977; Whittingham et al., 1979; Wood \& Farrant, 1980; Leibo et al., 1982; Renard et al., 1982; Rall et al., 1984a; Takeda et al., 1984).

Rall \& Fahy (1985a, b) described an alternative approach for the cryopreservation of mouse embryos by vitrification. Vitrification is a process of solidification whereby an aqueous solution does not crystallize during cooling; instead, the viscosity of the solution increases with decreasing temperature until an amorphous glass-like solid forms. Using this approach, 8-cell mouse embryos were exposed to a concentrated solution containing four cryoprotectants and then the embryo suspension was vitrified by cooling to liquid nitrogen temperature $\left(-196^{\circ} \mathrm{C}\right)$. When these vitrified embryos were warmed rapidly and diluted by a stepwise procedure, almost all of the embryos developed in culture to expanded blastocysts. In this paper we describe the production of live-born young that developed from embryos previously cryopreserved by vitrification. A preliminary report of these data has appeared elsewhere (Rall et al., 1985).

\footnotetext{
*Present address: Rio Vista International, Inc., Route 9, Box 242, San Antonio, Texas 78227, U.S.A.
} 


\section{Materials and Methods}

Source and isolation of embryos. Embryos were obtained from 3-7-week-old, random-bred MFI (Harlan-Olac Ltd, Bicester, U.K.) mice that were induced to superovulate by intraperitoneal injection of 5 i.u. PMSG (Folligon: Intervet, Cambridge, U.K.) and 5 i.u. hCG (Chorulon; Intervet) given $48 \mathrm{~h}$ apart. After the hCG injection, females were paired with MF1 males and inspected the following morning for copulation plugs. Embryos were flushed from the excised oviducts $42 \mathrm{~h}$ after the hCG injection using a modified Krebs-Ringer solution with Hepes buffer (Medium M2; Quinn et al., 1982). The normal 2- and 4-cell embryos were washed in fresh Medium M2, placed in drops of a bicarbonate-buffered embryo culture medium (Medium No. 16; Whittingham, 1971) under paraffin oil and incubated at $37^{\circ} \mathrm{C}$ in an atmosphere of $5 \% \mathrm{CO}_{2}$ in air. After $20 \mathrm{~h}$ culture the morphologically normal 8-cell embryos were washed in Medium M2 before equilibration with the vitrification solutions. Control embryos were cultured for $44 \mathrm{~h}$ to the morula or blastocyst stage before transfer to pseudopregnant recipients (see below).

Vitrification solutions. The solutions were those described previously (Rall \& Fahy, 1985a, b). The stock vitrification solution (for convenience designated VS1) consisted of a mixture of 3 permeating solutes $(20 \cdot 5 \%$ (w/v) dimethylsulphoxide, $15 \cdot 5 \%$ acetamide, $10 \%$ propylene giycol) and a non-penetrating polymer ( $6 \%$ (w/v) polyethylene glycol, $8000 M_{\mathrm{r}}$ ) in a modified Dulbecco's saline (final concentrations: $136.9 \mathrm{~mm}-\mathrm{NaCl}, 2.68 \mathrm{~mm}-\mathrm{KCl}, 0.25 \mathrm{~mm}-\mathrm{MgCl}$, $0.88 \mathrm{mM}-\mathrm{KH}_{2} \mathrm{PO}_{4}, 0.072 \mathrm{mM}-\mathrm{CaCl}_{2}, 5.56 \mathrm{~mm}$-glucose, $20 \mathrm{mM}$-Hepes, $0.75 \mathrm{mg}$ bovine serum albumin $/ \mathrm{ml}$ and $0.004 \%$ phenol red; $\mathrm{pH} \mathrm{8.0)}$. Dilutions of the Solution VSI were prepared using a Hepes-buffered saline (HBI: $136.9 \mathrm{~mm}-$ $\mathrm{NaCl}, 2.68 \mathrm{mM}-\mathrm{KCl}, 0.50 \mathrm{mM}-\mathrm{MgCl}_{2}, 1 \mathrm{~mm}-\mathrm{KH}_{2} \mathrm{PO}_{4}, 0.33 \mathrm{~mm}$-sodium pyruvate, $0.9 \mathrm{~mm}-\mathrm{CaCl}_{2}, 5.56 \mathrm{~mm}^{-g l u c o s e}$, $20 \mathrm{~mm}$-Hepes, $3 \mathrm{mg}$ bovine serum albumin $/ \mathrm{ml}$, $100 \mathrm{i}$.u. penicillin $\mathrm{G} / \mathrm{ml}$ and $0.004 \%$ phenol red; pH $7 \cdot 2$ ) to yield solutions with $12 \cdot 5 \%, 25 \%, 50 \%$ and $90 \%$ of the cryoprotectant concentrations in Solution VS1.

Exposure of embryos to vitrification solutions. The equilibration procedures were those described by Rall $\&$ Fahy (1985b). Briefly, groups of $20-40$-cell embryos were equilibrated in $25 \%$ solution VS1 at $\sim 20^{\circ} \mathrm{C}$ for 20 min. Embryos were then exposed to more concentrated solutions of Solution VS $l$ in a cold room $\left(\sim 4^{\circ} \mathrm{C}\right)$ to minimize any toxic effects of these solutions and prevent permeation of excessive cryoprotectants into the cytoplasm. After the embryo suspension was cooled to $\sim 4^{\circ} \mathrm{C}$, the embryos were transferred into $50 \%$ Solution VSI. After $10 \mathrm{~min}$, the embryos were transferred into the final vitrification solution ( 90 or $100 \%$ Solution VS1). After a total of 10 min exposure to the final vitrification solution, the embryos were either diluted without cooling or vitrified by rapid cooling in liquid $\mathrm{N}_{2}\left(-196^{\circ} \mathrm{C}\right)$.

Vitrification procedure. The embryo suspensions were vitrified in $0.25-\mathrm{ml}$ plastic insemination straws (No. A201, IMV, L'Aigle, France) prepared as follows. (1) A $1-\mathrm{cm}$ column of the appropriate final vitrification solution ( $90 \%$ or $100 \%$ Solution VS1) was carefully aspirated into a straw until the cotton/polyvinyl-alcohol plug was wetted. (2) A 2$\mathrm{cm}$ long column of the same VS1 solution was placed into the centre of the straw by using a glass syringe fitted with a 20 -gauge $8 \cdot 9-\mathrm{cm}$ hypodermic needle. The embryos were pipetted into the centre of this $2-\mathrm{cm}$ column and the straws were heat sealed. Care was taken during loading and sealing to prevent transient warming of the embryo suspension. After a total of $10 \mathrm{~min}$ exposure to the final vitrification solution, the straws were held in a vertical position and rapidly immersed in liquid $\mathrm{N}_{2}\left(\sim 2500^{\circ} \mathrm{C} / \mathrm{min}\right)$ where they were stored for periods between $1 \mathrm{~h}$ and 5 days.

Warming and dilution from vitrification solutions. The warming and initial dilution steps were carried out in the cold room $\left(\sim 4^{\circ} \mathrm{C}\right)$. The vitrified samples were warmed rapidly $\left(\sim 2500^{\circ} \mathrm{C} / \mathrm{min}\right)$ by vigorous shaking in a $\sim 2^{\circ} \mathrm{C}$ water bath. The contents of each straw $(90 \mu \mathrm{l})$ were expelled into $3 \mathrm{ml} 50 \%$ Solution VS1, mixed and held for $10 \mathrm{~min}$. The embryos were then transferred into $25 \%$ Solution VS1 for $10 \mathrm{~min}$. After being allowed to warm to room temperature $\left(\sim 20^{\circ} \mathrm{C}\right)$, the embryos were transferred into $12.5 \%$ Solution VS1 for a further $10 \mathrm{~min}$. Finally, the embryos were washed in Medium M2 and scored morphologically. Embryos that were diluted immediately after exposure to the vitrification solution without cooling below $4^{\circ} \mathrm{C}$ were transferred in $\sim 4 \mu$ l of the final solution into $3 \mathrm{ml} 50 \%$ Solution VSI at $4^{\circ} \mathrm{C}$ and then processed as above. All recovered embryos were washed in Medium No. 16 and cultured overnight in drops of the same medium under paraffin oil at $37^{\circ} \mathrm{C}$ in an atmosphere of $5 \% \mathrm{CO}_{2}$ in air.

Table 1. In-vitro development of 8 -cell mouse embryos vitrified in 90 or $100 \%$ Solution VS1

\begin{tabular}{|c|c|c|c|c|c|}
\hline \multirow{2}{*}{$\begin{array}{l}\text { Final conc. } \\
\text { Solution VSI }\end{array}$} & \multirow[b]{2}{*}{ Treatment } & \multicolumn{3}{|c|}{ No. of embryos } & \multirow{2}{*}{$\begin{array}{l}\text { No. of morulae and } \\
\text { Blastocysts after culture } \\
\text { for } 14-18 \mathrm{~h}(\%)\end{array}$} \\
\hline & & Treated & Recovered & $\begin{array}{l}\text { Normal at } \\
\text { recovery }(\%)\end{array}$ & \\
\hline $90 \%$ & $\begin{array}{l}\text { Immediate dilution } \\
\text { Vitrified }\end{array}$ & $\begin{array}{r}82(2)^{*} \\
568(17)^{*}\end{array}$ & $\begin{array}{r}82 \\
547\end{array}$ & $\begin{aligned} 81 & (99) \\
447 & (82)\end{aligned}$ & $\begin{array}{r}72(88) \\
440(80)\end{array}$ \\
\hline $100 \%$ & $\begin{array}{l}\text { Immediate dilution } \\
\text { Vitrified }\end{array}$ & $\begin{aligned} 83 & (2)^{*} \\
153 & (8)^{*}\end{aligned}$ & $\begin{array}{r}82 \\
145\end{array}$ & $\begin{array}{r}82(100) \\
108(74)\end{array}$ & $\begin{array}{l}43(52) \\
32(22)\end{array}$ \\
\hline
\end{tabular}

*Number of replicate samples. 
In-vivo development of embryos. After overnight culture, all embryos resuming development, including those with damaged blastomeres and some embryos arrested at the 8-cell stage, were transferred into the uterine horns (4-6 embryos per horn) of 100 recipient females on Day 3 of pseudopregnancy. The recipients were CBB (CBA/Ca $\mathrm{Nimr} q \times \mathrm{C} 57 \mathrm{BL} / \mathrm{Nimr} \delta)$ or B6CB (C57BL/6J Lac $q \times \mathrm{CBA} / \mathrm{Ca}$ Lac $\delta)$ F1 hybrids that had been naturally mated with sterile males carrying the translocation T145 (Lyon \& Meredith, 1966). Not all females successfully mated to sterile males establish pregnancy after embryo transfer. To minimize the risk of losing a disproportionate number of embryos from a single treatment, morulae and blastocysts from one of the four treatment groups and controls cultured for $44 \mathrm{~h}$ were randomly assigned to each uterine horn of 40 recipients (Bowman \& McLaren, 1970a). These females were autopsied on Day 15 or 16 of gestation, and the total number of implantation sites and normal fetuses in each horn was recorded. The remaining 60 recipients received embryos from the same treatment group in both uterine horns. Of these recipients, 42 were autopsied on Day 15 or 16 of gestation, and the remaining 18 were allowed to carry their litters to term.

\section{Results}

The recovery and in-vitro development of 8-cell mouse embryos equilibrated in vitrification solutions and then diluted immediately or after vitrification are summarized in Table 1. Nearly all of the embryos diluted immediately after equilibration in 90 or $100 \%$ Solution VS1 were normal at recovery. However, vitrification in 90 or $100 \%$ Solution VS1 significantly reduced the proportion of normal embryos compared to those diluted immediately $\left(\chi_{1}^{2}=17.6, P<0.001\right.$ and $\chi_{1}^{2}=25.5$, $P<0.001$, respectively). A high proportion of embryos ( $>80 \%$ ) developed in vitro to morulae and blastocysts after equilibration in $90 \%$ Solution VS1, regardless of whether the embryos were vitrified. However, embryos diluted immediately after equilibration in $100 \%$ Solution VS1 exhibited a significantly lower rate of development compared to those diluted immediately from $90 \%$ Solution VSI (52 versus $88 \% ; \chi_{1}^{2}=23.6, P<0.001$ ). Vitrification of embryos in $100 \%$ Solution VSI significantly reduced their ability to develop in culture compared to those diluted immediately $\left(\chi_{1}^{2}=167.9, P<0.001\right)$. Considerable variability was observed between the ability of replicate groups of embryos equilibrated in $100 \%$ Solution VS1 to develop in culture. For example,

Table 2. Post-implantation development of 8 -cell mouse embryos after vitrification in 90 or $100 \%$ Solution VS1, rapid warming and transfer to pseudopregnant recipients

\begin{tabular}{|c|c|c|c|c|c|c|c|}
\hline \multirow[b]{2}{*}{$\begin{array}{l}\text { Final conc. } \\
\text { Solution VS1 }\end{array}$} & \multirow[b]{2}{*}{ Treatment } & \multicolumn{2}{|c|}{$\begin{array}{c}\text { No. of } \\
\text { embryos transferred* }\end{array}$} & \multicolumn{2}{|c|}{ On Day $14-16$ of gestation } & \multirow[b]{2}{*}{$\begin{array}{c}\text { No. of live } \\
\text { young at } \\
\text { birth } \\
(\%) \ddagger\end{array}$} & \multirow[b]{2}{*}{$\begin{array}{c}\text { Estimated } \\
\text { overall } \\
\text { survival } \\
(\%) \dagger\end{array}$} \\
\hline & & Total & $\begin{array}{c}\text { To females } \\
\text { establishing } \\
\text { pregnancy }\end{array}$ & $\begin{array}{c}\text { No. of } \\
\text { implantation } \\
\text { sites } \\
(\%) \ddagger\end{array}$ & $\begin{array}{c}\text { No. of } \\
\text { normal } \\
\text { fetuses } \\
(\%) \ddagger\end{array}$ & & \\
\hline $90 \%$ & $\begin{array}{c}\text { Immediate } \\
\text { dilution }\end{array}$ & $\begin{array}{l}62 \\
19\end{array}$ & $\begin{array}{l}52 \\
19\end{array}$ & $33(64)$ & $14(27)$ & $\overline{7(37)}$ & 26 \\
\hline & Vitrified & $\begin{array}{l}356 \\
112\end{array}$ & $\begin{array}{l}247 \\
112\end{array}$ & $124(50)$ & $\begin{array}{c}64(26) \\
-\end{array}$ & $34(30)$ & 17 \\
\hline \multirow[t]{2}{*}{$100 \%$} & $\begin{array}{c}\text { Immediate } \\
\text { dilution }\end{array}$ & 48 & 44 & $29(66)$ & $18(41)$ & - & 22 \\
\hline & Vitrified & 48 & 30 & $9(30)$ & $1(3)$ & - & 1 \\
\hline - & $\begin{array}{l}\text { Untreated } \\
\text { control }\end{array}$ & $\begin{array}{r}382 \\
60\end{array}$ & $\begin{array}{r}370 \\
60\end{array}$ & $267(72)$ & $218(59)$ & $29 \overline{(48)}$ & 56 \\
\hline
\end{tabular}

\footnotetext{
*All morulae, blastocysts and some '8-cells' after culture were transferred into the uterus of a recipient on Day 3 of pseudopregnancy.

$\dagger$ Expressed as percentage of the number of embryos treated (see Table 1).

$¥$ Based on number of embryos transferred to females establishing pregnancy.
} 
the rate of development of embryos diluted immediately varied from $17 \%(n=42)$ to $90 \%(n=40)$, and from $0 \%(n=51,3$ replicates) to $55 \%(n=20)$ for vitrified embryos. Most of the embryos exposed to $100 \%$ Solution VS1 that did not develop in culture were arrested at the 8-cell stage.

The in-vivo development of embryos after equilibration in VS1 solutions, vitrification and transfer to pseudopregnant recipients is summarized in Table 2. Altogether, 1087 treated and control embryos were transferred to 100 recipients and 85 of these females established pregnancy. In the 67 pregnant recipients examined on Day 15 or 16 of gestation, 462 implantation sites $(62.2 \%)$ and 315 normal live fetuses $(42.4 \%)$ were found. The rate of implantation observed for untreated control embryos was not statistically different from that of embryos diluted immediately after equilibration in 90 or $100 \%$ Solution VS1. Vitrification in 90 or $100 \%$ Solution VS1, however, significantly reduced the rates of implantation when compared to that obtained when embryos were diluted immediately $\left(\chi_{1}^{2}=4.9, P<0.05\right.$ and $\chi_{1}^{2}=7.8, P<0.01$, respectively). The proportion of treated embryos that developed to normal fetuses was significantly lower than that of untreated control embryos $\left(\chi_{1}^{2}\right.$ analysis, $\left.P<0.001\right)$. This difference reflects an increase in the post-implantation mortality of the treated embryos. Early post-implantation mortality was similar in all treated embryo groups $(\sim 50 \%)$, except for those vitrified in $100 \%$ Solution VSI in which only 1 of 9 implantations was a normal fetus.

For the 18 recipients allowed to litter, there were 41 young from embryos exposed to $90 \%$ Solution VS1 and 29 young from untreated control embryos. All progeny were phenotypically normal. The reproductive performance of progeny was tested by pairing 7-week-old offspring from the same treatment groups. Seven females derived from vitrified embryos were paired with 7 males from the same treatment and yielded a total of 77 normal young with litter sizes ranging from 4 to 16. Similarly, 4 females derived from embryos diluted immediately were mated with 3 males from the same treatment and yielded a total of 47 normal young in litters of 5 to 15 .

\section{Discussion}

Normal development to late-stage fetuses and liveborn young was obtained from 8-cell mouse embryos cryopreserved by vitrification of the entire embryo suspension. Furthermore, the progeny derived from vitrified embryos were phenotypically normal, fertile and produced normal offspring. The overall efficiency of cryopreservation by the vitrification of random-bred MF1 embryos in $90 \%$ Solution VS1 (17\%; Table 2) is lower than that estimated for embryos of the same strain cryopreserved by conventional freezing methods $(\sim 50 \%$, Whittingham et al., 1979). By contrast, Scheffen et al. (1986) reported that about $30 \%$ of Day 4 mouse embryos develop when transferred to recipients either immediately or after vitrification in a different vitrification solution.

Our results indicate that exposure of embryos to concentrated solutions of VS1 reduced their ability to develop in vivo into normal fetuses and liveborn young. The loss occurs mainly in the early post-implantation period. It is unusual for preimplantation embryos to implant after exposure to a toxic solution and then to die as a result of the exposure. Early post-implantation mortality may reflect slower development of embryos in vitro after dilution, producing blastocysts with an insufficient number of cells to permit normal development and differentiation of an inner cell mass. Such an effect may have been magnified by culturing the embryos for $20 \mathrm{~h}$ before equilibration in the vitrification solutions (Bowman \& McLaren, 1970b). Alternatively, the VS1 solution or its residues may have a specific toxic effect on the cells destined to become the inner cell mass in a manner analogous to the toxic effects of $\left[{ }^{3} \mathrm{H}\right]$ thymidine residues (Snow, 1973). Embryonic development of mouse embryos is delayed after conventional cryopreservation (Whittingham \& Anderson, 1976), and a similar delay may occur after vitrification.

Embryos exposed to $90 \%$ Solution VS1 exhibit a high rate of development in vitro when diluted without cooling below $4^{\circ} \mathrm{C}$; a result similar to that reported by Rall \& Fahy (1985b). However, in contrast to the previous study in which similar high rates of development were obtained after 
exposure to 90 or $100 \%$ Solution VS1, we found that development in vitro was significantly reduced after exposure to the more concentrated solution. The deleterious effect of equilibration in $100 \%$ Solution VS1 presumably reflects the higher susceptibility of embryos to chemical toxicity and osmotic injury when exposed to this concentrated solution (Rall \& Fahy, 1985b; Rall, 1987). This explanation of injury is supported by the fact that those embryos that failed to develop were arrested at the 8-cell stage, an observation previously associated with the toxic effects of prolonged exposure to Solution VS1 (Rall \& Fahy, 1985b; W. F. Rall, unpublished observations). The additional steps associated with vitrification resulted in a further reduction of the in-vitro development of the embryos even though the physical process of solidification during cooling per se ought to be innocuous (Fahy et al., 1984; Rall et al., 1984b; Rall \& Polge, 1984). Two subtle differences in the procedures used to dilute embryos immediately or after vitrification may account for some of the extra injury observed after vitrification. First, the larger volume of embryo-vitrification solution in the straw increased the difficulty of obtaining rapid mixing during the first dilution step. Secondly, vitrified embryos were exposed to the final vitrification solution for an additional 2-3 min after warming as the straws were prepared for dilution. Recent work suggests that the use of a sucrose dilution procedure (Leibo \& Mazur, 1978) in combination with a propylene glycol-or glycerol-based vitrification solution (Rall, 1986, 1987) or a mixture of propylene glycol and glycerol (Scheffen $e t$ al., 1986) will reduce toxic and osmotic injury after vitrification.

Vitrification of the cytoplasm and a small portion of the extracellular solution has been shown to be important during conventional embryo cryopreservation procedures (Rall \& Polge, 1984; Rall et al., 1984b). A knowledge of the ability of embryo-VS1 suspensions to avoid crystallization during cooling and warming is critical to our interpretation that survival is associated with vitrification. Evidence for the complete vitrification of embryo-VS1 suspensions has been discussed by Rall \& Fahy (1985b), and confirmed by detailed calorimetric and cryomicroscopical studies of $90 \%$ and 100\% Solution VS1 (Reid et al., 1985) and 93\% Solution VS1 (Takahashi et al., 1986). A complete description of the cryobiological factors associated with successful preservation by vitrification will appear elsewhere (Rall, 1987).

Vitrification, in addition to providing a simple and rapid method for the cryopreservation of mammalian cells and embryos, offers new opportunities to examine fundamental aspects of cryoprotection and cryoinjury. Improved methods for the long-term cryopreservation of mammalian embryos by vitrification of the entire suspension will depend on the development of less toxic vitrification solutions and procedures that will minimize osmotic stresses during equilibration and dilution.

\section{References}

Bowman, P. \& McLaren, A. (1970a) Viability and growth of mouse embryos after in vitro culture and fusion. $J$. Embryol. exp. Morph. 23, 693-704.

Bowman, P. \& McLaren, A. (1970b) Cleavage rate of mouse embryos in vitro and in vivo. J. Embryol. exp. Morph. 24, 203-207.

Fahy, G.M., MacFarlane, D.R., Angell, C.A. \& Meryman, H.T. (1984) Vitrification as an approach to cryopreservation. Cryobiology 21, 407-426.

Leibo, S.P. (1977) Fundamental cryobiology of mouse ova and embryos. In The Freezing of Mammalian Embryos (Ciba Fdn Symp. No. 52), pp. 69-92. Eds K. Elliott \& J. Whelan. Elsevier, Amsterdam.

Leibo, S.P. \& Mazur, P. (1978) Methods for the preservation of mammalian embryos by freezing. In Methods in Mammalian Reproduction, pp. 179-201. Ed. J. Daniels. Academic Press, Inc., New York.
Leibo, S.P., Mazur, P. \& Jackowski, S.C. (1974) Factors affecting survival of mouse embryos during freezing and thawing. Expl Cell Res. 89, 79-88.

Leibo, S.P., West, A.W., III \& Perry, B. (1982) A onestep method for direct nonsurgical transfer of frozenthawed bovine embryos. I. Basic studies. Cryobiology 19, 673-674, Abstr.

Lyon, M.F. \& Meredith, R. (1966) Autosomal translocations causing male sterility and variable aneuploidy in the mouse. Cytogenetics 5, 335-354.

Quinn, P., Barros, C. \& Whittingham, D.G. (1982) Preservation of hamster oocytes to assay the fertilizing capacity of human spermatozoa. J. Reprod. Fert. 66, 161-168.

Rall, W.F. (1986) Cryopreservation of mouse embryos by vitrification. Cryobiology 23, 548, Abstr.

Rall, W.F. (1987) Factors affecting the survival of mouse 
embryos cryopreserved by vitrification. Cryobiology (in press).

Rall, W.F. \& Fahy, G.M. (1985a) Vitrification: a new approach to embryo cryopreservation. Theriogeno$\log y$ 23, 220, Abstr.

Rall, W.F. \& Fahy, G.M. (1985b) Ice-free cryopreservation of mouse embryos at $-196^{\circ} \mathrm{C}$ by vitrification. Nature, Lond. 313, 573-575.

Rall, W.F. \& Polge, C. (1984) Effect of warming rate on mouse embryos frozen and thawed in glycerol. $J$. Reprod. Fert. 70, 285-292.

Rall, W.F., Czlonkowska, M., Barton, S.C. \& Polge, C. (1984a) Cryoprotection of Day-4 mouse embryos by methanol. J. Reprod. Fert. 70, 293-300.

Rall, W.F., Reid, D.S. \& Polge, C. (1984b) Analysis of slow-warming injury of mouse embryos by cryomicroscopical and physiochemical methods. Cryobiology 21, 106-121.

Rall, W.F., Wood, M.J. \& Kirby, C. (1985) In vivo development of mouse embryos cryopreserved by vitrification. Cryobiology 22, 603-604, Abstr.

Reid, D.S., Rall, W.F. \& Fahy, G.M. (1985) DSC and cryomicroscope studies of the behavior of VS1 solutions at low temperatures. Cryobiology 22, 602, Abstr.

Renard, J.P., Heyman, Y. \& Ozil, J.P. (1982) Congelation de l'embryon bovin: une nouvelle methode de decongelation pour le transfert cervical d'embryons conditionnes une seule fois en paillettes. Annls Med. Vet. 126, 23-32.

Schefien, B., Van der Zwalmen, P. \& Massip, A. (1986) A simple and efficient procedure for the preservation of mouse embryos by vitrification. Cryo-Letters 7, 260-269.

Snow, M.H.L. (1973) The differential effect of ${ }^{3} \mathrm{H}$ thymidine upon two populations of cells in preimplantation mouse embryos. In The Cell Cycle in Development and Differentiation, pp. 311-324. Eds M. Balls \& F. S. Billet. Cambridge University Press.
Takahashi, T., Hirsh, A., Erbe, E.F., Bross, J.B., Steere, R.L. \& Williams, R.J. (1986) Vitrification of human monocytes. Cryobiology 23, 103-115.

Takeda, T., Elsden, R.P. \& Seidel, G.E., Jr (1984) Cryopreservation of mouse embryos by direct plunging into liquid nitrogen. Theriogenology 21, 226, Abstr.

Whittingham, D.G. (1971) Culture of mouse ova. $J$. Reprod. Fert., Suppl. 14, 7-21.

Whittingham, D.G. (1977) Some factors affecting embryo storage in laboratory animals. In The Freezing of Mammalian Embryos, pp. 97-127. Eds K. Elliott \& J. Whelan. Elsevier/North Holland, Amsterdam.

Whittingham, D.G. \& Anderson, E. (1976) Ultrastructural studies of frozen-thawed 8-cell mouse embryos. $J$. Reprod. Fert. 48, 137-140.

Whittingham, D.G., Leibo, S.P. \& Mazur, P. (1972) Survival of mouse embryos frozen to $-196^{\circ} \mathrm{C}$ and $-269^{\circ}$ C. Science, N.Y. 178, 411-414.

Whittingham, D.G., Wood, M.J., Farrant, J., Lee, H. \& Halsey, J.A. (1979) Survival of frozen mouse embryos after rapid thawing from $-196^{\circ}$ C. J. Reprod. Fert. 56, $11-21$.

Willadsen, S.M. (1977) Factors affecting the survival of sheep embryos during deep-freezing and thawing. In The Freezing of Mammalian Embryos, pp. 175-201. Eds K. Elliott \& J. Whelan. Elsevier/North Holland, Amsterdam.

Wilmut, I. (1972) The effect of cooling rate, warming rate, cryoprotective agent, and stage of development on survival of mouse embryos during freezing and thawing. Life Sci. 11, 1071-1079.

Wood, M.J. \& Farrant, J. (1980) Preservation of mouse embryos by two-step freezing. Cryobiology 17, $178-180$. 